\title{
34 \\ THE UNITED KINGDOM'S APPROACH TO COUNTERTERRORISM
}

\author{
Robin Simcox and Hannah Stuart
}

The United Kingdom suffered its first major Islamist terrorist attack on July 7, 2005. In the years that followed, it faced several more attacks, including five separate incidents in 2017. ${ }^{1}$ Since September 2001, acts of terrorism carried out in Great Britain ${ }^{2}$ have led to 97 deaths. ${ }^{3}$

The United Kingdom had hosted, and even provided refuge to, Islamist-inspired activists long before it began to be targeted by jihadi terrorists. These activists helped embed Islamist perspectives and attitudes within elements of Britain's Muslim communities that likely made jihadi recruiters' task easier in the decades to come.

This chapter offers a brief overview of the origins of Islamism in the United Kingdom. It then explains how the 9/11 attacks resulted in the United Kingdom fighting terrorism abroad to prevent attacks on British soil. Next, it discusses the impact of the London bombings in 2005, which caused the United Kingdom to focus its counterterrorism approach on homegrown terrorism. It then examines the impact of the Islamic State and its self-proclaimed caliphate on the United Kingdom. Finally, the chapter briefly examines the diversity of European responses in combating Islamist terrorism.

\section{Islamism in the United Kingdom}

The Islamist terrorism threat to the United Kingdom today comes predominantly from Salafi-jihadi groups, such as the Islamic State and al-Qaida. ${ }^{4}$ The broader spectrum of Islamism-understood as the organized effort to advocate for Sharia (Islamic law) as the basis for society and the state- has a distinct history in Britain dating back decades. ${ }^{5}$

Mainstream Islamism has its origins in two 20th-century movements, al-Ikhwan al-Muslimin (est. 1928, Egypt), known as the Muslim Brotherhood, and Jamaat-i-Islami (est. 1941, India) in South Asia. ${ }^{6}$ While Islamists in the West today have mostly abandoned the aim of a Sharia-governed state in their own country for now, they belong to a trans-ethnic network of like-minded individuals and groups that work through institutions and mosque networks to revive their understanding of Islam in all aspects of social and political life. ${ }^{7}$ In the United Kingdom, mainstream Islamists sometimes refer to themselves as the "Islamic Movement" and operate across multiple spheres, including education, welfare, community activism, media, and advocacy.

These organizations comprised mainly exiles and overseas students. Fifty years ago, many Muslim Brotherhood-inspired groups in the United Kingdom prioritized recruiting members who would support 
the cause in the Middle East. ${ }^{8}$ Other older Jamaati-i-Islami inspired groups were established to serve specific ethnic or linguistic Muslim communities living in the United Kingdom. ${ }^{9}$

From the 1980s and 1990s onwards, however, mainstream Islamists developed a more cohesive approach to engaging with Britain's diverse settled Muslim communities, resulting in the creation of several ostensibly national, umbrella Muslim bodies. Groups such as the Muslim Association of Britain and the Muslim Council of Britain sought to promote their Islamist views and to serve as interlocutors between the government, British Muslims, and recently the media. ${ }^{10}$

This new strategy was in part a response to challenges posed by militant Salafis to the authority of Britain's Brotherhood and Jamaati-inspired groups. These militant Salafis had returned to the United Kingdom having fought with the mujahidin in Afghanistan during the war against the Soviet Union and the factional fighting that followed. ${ }^{11}$ Several high-profile exiles and former mujahidin claimed asylum in the United Kingdom in the 1980s and 1990s and promoted Salafi-jihadi ideas among young British Muslims. ${ }^{12}$ Preaching in mosques across the country—but particularly focused on London-these clerics helped inject international jihadi causes into the bloodstream of British Islam.

Key to this was Bosnia, where Western inaction in response to the persecution of Muslims-which included, most emotively and profoundly, the Serb slaughter of Bosniak Muslims in Srebrenica in July 1995-energized an Islamist narrative that warned that when it came to Muslim suffering, nonMuslims were at best indifferent and worst complicit. ${ }^{13} \mathrm{~A}$ small number of Brits headed to Bosnia to fight in defense of Muslims, with pro-mujahidin online forums subsequently glorifying their "martyrdom." 14 Survivors of the conflict emerged as key Islamist recruiters for years to come, in part due to the legitimacy that fighting in Bosnia bestowed upon them in certain circles. ${ }^{15}$

In addition, Brotherhood and Jamaati Islamist groups were also being challenged by the emergence in the United Kingdom of revolutionary Islamist groups Hizb ut-Tahrir and al-Muhajiroun, which, dissatisfied with the gradualist approach of mainstream Islamist groups, advocated a more radical means to capture state power. ${ }^{16}$

A violent brand of Islamism was clearly developing in the United Kingdom. Yet the presence of these extremist discourses, such as justifying suicide bombing and the killing of civilians overseas, was tacitly tolerated by the British authorities in return for self-policing and an understanding that there would be no bombs on the streets of the United Kingdom. ${ }^{17}$

It would later become clear that such Islamist ideologues had paved the way-ideologically and operationally - for the al-Qaida networks operating in the United Kingdom in the 2000s. ${ }^{18}$ Yet it was not in the United Kingdom where Western policymakers first had to confront how devastating a lax approach toward this increasingly ambitious Salafi-jihadi movement could be. It was in the United States.

\section{The impact of the 9/11 attacks on the UK}

The British government's support for the United States following al-Qaida's terrorist attacks on September 11, 2001, was unflinching. Prime Minister Tony Blair proclaimed that the United Kingdom would "stand shoulder to shoulder" with the United States and that "we, like them, will not rest until this evil is driven from our world." ${ }^{19}$ They were not empty words. On October 7, 2001, Blair announced that British forces were fighting at the side of U.S. soldiers in Afghanistan, targeting al-Qaida and the Taliban. The Special Air Service were deployed on the ground while the Royal Navy targeted terrorist training camps and bases from the sea. ${ }^{20}$

Soon enough, British troops discovered that they were fighting against some of their own countrymen on the battlefield: British Muslims who had left to defend the Taliban and al-Qaida. ${ }^{21}$ Reports quickly emerged of British Muslims killed in the fighting. ${ }^{22}$ Others ended up detained at Guantanamo Bay (although most would later claim to be innocent of taking part in any fighting). ${ }^{23}$ 
Inevitably, the United Kingdom began to contemplate how best to avoid a domestic attack. It had faced a tiny number of Islamist terrorist plots prior to $9 / 11 .{ }^{24}$ The most significant was planned by Moinul Abedin, who had trained in the Afghanistan-Pakistan region in 1996 and was arrested by British police in November 2000 over a nascent plan to use explosives. He was sentenced to 20 years in jail for what the judge described as "a serious plot." 25 But the perception of the threat in the wake of 9/11 was similar to the United States: how to strengthen one's defenses at home to stave off attacks planned overseas.

That meant updating legislation. In December 2001, the government passed the Anti-Terrorism, Crime and Security Act 2001. This legislation included a focus on increased intelligence sharing, terror financing, aviation security, as well as strengthening security around nuclear sites. ${ }^{26}$

It also strengthened government powers on immigration and asylum. The United Kingdom said it faced a "public emergency" from certain "foreign nationals ... who are a threat to the national security of the United Kingdom." ${ }^{27}$ Yet deportation was not an option the United Kingdom could easily pursue: these men were from countries with poor human rights records. A 1996 European Court of Human Rights ruling had established a precedent where national security concerns were essentially irrelevant when weighed against human rights of the individual. ${ }^{28}$ Therefore, any attempt to deport these men would lead to a breach of Article 3 of the European Convention on Human Rights (prohibition of torture).

The government subsequently signaled the United Kingdom's intent to derogate from parts of Article 5 of the European Convention on Human Rights, pertaining to the right to liberty and security, to be able to detain, without trial, foreign national security threats that it could not deport. ${ }^{29}$ The United Kingdom quickly arrested nine such terrorism suspects and detained them at Belmarsh Prison in southeast London. This included Abu Qatada, a Palestinian theologian close to various jihadi groups (including al-Qaida) and whom a litany of home secretaries would spend the next decade trying to deport back to Jordan.

When it could, the government also prosecuted Islamist ideologues based in the United Kingdom. In February 2002, for example, the British government charged Abdullah el-Faisal with offenses that ultimately resulted in his conviction of soliciting to murder and inciting racial hatred based on sermons where he urged his audiences to wage jihad. A Jamaican convert to Islam, el-Faisal preached to study groups and universities throughout the United Kingdom. ${ }^{30}$

There also was Abu Hamza al-Masri, the imam at Finsbury Park Mosque in north London, who had gained significant notoriety in the British press due to his incendiary speeches. ${ }^{31}$ In August 2004, he was arrested on charges that led to his conviction of multiple counts of soliciting to murder and inciting racial hatred based on speeches made between 1997 and 2000.

This state clampdown on jihadi preachers was a necessary, albeit belated, response to the pernicious influence they had wielded over the previous decade. Yet it became increasingly clear that such measures were inadequate. The ideas pumped out by foreign clerics had long been heard by British Muslims. ${ }^{32}$ Now they were beginning to act on them.

\section{The impact of the 7/7 London bombings on the UK}

On July 7, 2005 (known as “7/7”), four suicide bombings on the London transport network killed 52 people. It had a profound effect on how the government and wider society came to understand the nature of the threat it faced. The four al-Qaida-trained bombers-led by special needs teaching assistant Mohammed Sidique Khan — had all been raised in the United Kingdom. Islamism was no longer primarily viewed as a foreign threat; instead, the terms "homegrown" and "radicalization" were commonly utilized by those seeking to explain how and why the attack had happened.

Speaking in a strong Yorkshire accent in a video released after the attack, Khan told his fellow Britons, "Your democratically elected governments continuously perpetuate atrocities against my people all over the world," before making the case that he is "directly responsible for protecting and avenging my Muslim 
brothers and sisters." While ostensibly an expression of anger at British foreign policy, Khan's language revealed that he saw himself as a "true inheritor of the prophet," defending Islam from the West. "We are at war," he said, "and I am a soldier." 33

Responding to public alarm, Blair announced that "the rules of the game have changed" as he set out a series of commitments to keep the country safe. ${ }^{34}$ Some of these measures were introduced quickly, such as powers to exclude foreign nationals on the grounds of extremism-related "unacceptable behaviors." ${ }^{35}$ The Terrorism Act 2006 made it an offense to encourage or glorify terrorism. This paved the way that year for the proscription of al-Ghurabaa and the Saved Sect, the two names under which the extremist group al-Muhajiroun operated following then leader Omar Bakri Muhammed's public disbanding of the group in 2004.

This marked the first proscription of an Islamist group that was based and operated in the United Kingdom. ${ }^{36}$ Other measures — such as the proscription of Hizb-ut-Tahrir (out of which al-Muhajiroun had previously emerged $)^{37}$ and a power to order closure of places of worship for fomenting extremism-were abandoned, having been found disproportionate or unworkable.

Arguably, however, the area where Blair most influenced events was in his desire to root out Islamist extremism within Britain's Muslim communities. Under his leadership, the United Kingdom shifted away from relying solely on the traditional policing or military approach to counterterrorism that had characterized the conflict in Northern Ireland toward a focus on interventions and stopping people from being attracted to extremism and terrorism in the first place. This initiative was known as Prevent. ${ }^{38}$

Prevent began in the form of "Preventing Extremism Together" working groups with Muslim faith and community leaders. Set up to provide practical recommendations on the themes of young people, education, women, civil society, mosques, community security, and extremism, they published an action plan containing numerous recommendations, including a national advisory board for mosques and imams, a roadshow of Muslim scholars to counter extremist ideas, and actions to tackle assumed drivers of radicalization, such as inequality and discrimination. ${ }^{39}$

Four distinct approaches emerged to address the challenge of radicalization: tackling "disadvantages" and "grievances" that can contribute to radicalization, deterring or disrupting those who promote violent extremism, "engaging in the battle of ideas" to debunk the ideologies behind violence, ${ }^{40}$ and supporting individuals who may be vulnerable to recruitment by violent extremists—a precursor to today's safeguarding focus. ${ }^{41}$

In many ways, Prevent's approaches mirrored discussions in academia and policy institutions on how best to understand and respond to homegrown radicalization. Early debates had focused on the extent to which ideology was a driving factor attracting people to terrorism, as opposed to grievances, in particular foreign policy, and other drivers such as socioeconomics and disenfranchisement.

In the two years before the $7 / 7$ attacks, Khan had been a trustee at a charity bookshop. He had used the venue to give lectures, criticizing Western foreign policy, and supporting suicide bombing in Palestine after he had been moved on from several local mosques for "inappropriate behavior." ${ }^{2}$ Policymakers rightly raised questions around the role of institutions - such as mosques, charities, and gyms - the reach and influence of charismatic preachers, and the internet as venues for mobilization to engage in violent extremism.

Above all, Prevent envisaged "winning hearts and minds" through community-centered and community-led projects to tackle violent extremism at a local level. ${ }^{43}$ Police involvement, however, led to accusations in the media that the strategy justified spying on Muslim communities ${ }^{44}$ and in academia that it blurred the lines between policing and the security services, securitizing Muslim communities, and integration efforts. ${ }^{45}$ The Equality and Human Rights Commission warned of a "danger that Muslims in contemporary Britain may become the new suspect community." ${ }^{66}$ The government was also quickly mired in Prevent funding and engagement controversies, some of which continue to this day. ${ }^{47}$ 
Mainstream Islamists and their supporters in government and public bodies had argued for the inclusion of more radical voices, so long as they were willing to reject terrorism in the United Kingdom. ${ }^{48}$ Influential foreign scholars, such as Muslim Brotherhood spiritual leader Yusuf al-Qaradawi, they argued, were well placed to tackle violent interpretations of Islam. ${ }^{49}$ Al-Qaradawi's form of political Islam was regarded as a "safety valve" for disaffected young Muslims who may otherwise have turned to terrorism in the UK homeland. In practice, this approach meant that government funding went to groups accused of having links to the Brotherhood, as well as to individuals and groups espousing views at odds with the United Kingdom's Western democratic values. ${ }^{50}$

For some, the line between supposedly non-violent political Islam and violent Islamist terrorism was not so clear. Momentum began to form around the notion that those who eschew terrorism in the United Kingdom but still believe that, in certain contexts, the targeting of civilians or Western forces in Muslimmajority countries is legitimate, or who agitate for the return of the caliphate, were not the solution. Instead, they were part of the problem and rather than having their voices amplified should instead be excluded from government counterextremism efforts. ${ }^{51}$

With the United Kingdom being the target of several other al-Qaida-linked plots in the years after 7/7, and with the threat showing no sign of abating, it was these more hawkish voices that increasingly gained prominence. This outlook found a voice in new Prime Minister David Cameron. In his 2011 Munich Security Conference speech, he argued for a shift away from the laissez-faire "doctrine of state multiculturalism," which had allowed people from different religions and backgrounds to live separate, parallel lives, and away from "passive tolerance" of intolerance. In seeking to confront the ideological challenge of Islamist extremism, he was clear that government and wider society should be more confident in its liberal values. ${ }^{52}$

In 2015, he remarked that the government needed to be clear about the ideological nature of the threat to better understand the ways in which Islamist extremists exploited grievances and injustice and not to accept their characterization of an oppressed Muslim community subject to attacks from Jews or the West. ${ }^{53}$

This revision in attitudes toward Islamists, both violent and non-violent, can be tracked to the election of the coalition government in 2010 and the subsequent independent review of Prevent. The 2011 review re-cast Prevent, transforming what was previously a narrow focus on opposing violent extremism (on British shores) into a commitment to respond to the "ideological challenge of terrorism," which included ruling out working with or funding organizations that did not accept the fundamental values of "universal human rights, equality before the law, democracy and full participation in our society." 54

Through Prevent, the United Kingdom attempted to head off the homegrown threat. All the while, however, it was also facing legal issues dating back to the 2001 Act after the nine foreign national terror suspects housed at Belmarsh Prison had appealed the legality of their detention to the European Court of Human Rights. In December 2004, the court ruled against the British government. It declared that the 2001 Act was incompatible with Article 5 (right to liberty and security), as the United Kingdom had not made the case that it faced a "public emergency threatening the life of the nation" and derogation from Article 5 to detain these terror suspects was a disproportionate response. It went on to conclude that the Act was also incompatible with Article 14 (prohibition of discrimination), as it was discriminating against the terror suspects based on their nationality. ${ }^{55}$

Despite the court ruling, the government deemed these terror suspects too dangerous to set free. It therefore passed the Prevention of Terrorism Act in March 2005, which allowed the government to place a terror suspect under a Control Order. ${ }^{56}$ This was a measure allowing the state to impose a series of restrictions on individuals to prevent or limit their involvement in suspected terrorist activities. It included home curfew, electronic tagging, banning travel abroad, relocation powers, and prohibiting the use of certain electronic devices. ${ }^{57}$

Control Orders, too, would face legal challenges that led to some of these restrictions becoming less onerous (for example, the length of home curfew) ${ }^{58}$ The system remained in place, however, until it was 
replaced by a new government with Terrorism Prevention and Investigation Measures in 2011, which paid lip service to being less intrusive toward terror suspects but were, for all intents and purposes, simply Control Orders repackaged and rebranded. ${ }^{59}$ These measures remain in operation today and can be served against British citizens as well as foreign nationals.

All the while, the fundamental issue that led to both detention without trial and then Control Ordersthe inability to deport foreign terror suspects to countries with poor human rights records-was being chipped away at the margins. The government negotiated deportation with assurances agreements with Algeria, Ethiopia, Jordan, Lebanon, Libya, and Morocco between 2005 and 2011, containing safeguards that allowed deportations to occur that did not imperil the human rights of the deportee nor contravene international law. ${ }^{60}$

The most symbolic victory for this approach occurred in July 2013, when extremist cleric Abu Qatada was sent to Jordan to face trial after sufficient assurances were received that no evidence gained via torture could be used against him during criminal hearings. In September 2014, Qatada was acquitted of terrorism offenses in Amman. ${ }^{61}$

\section{The caliphate and beyond}

On June 30, 2014, the Islamic State of Iraq and Syria declared a caliphate spanning from Diyala in eastern Iraq to Aleppo in northern Syria. The group renamed itself the Islamic State, and it began beheading Western hostages - including two British citizens - in grisly propaganda videos disseminated around the world. The balaclava-clad executioner had a British accent and was later revealed to be Mohammed Emwazi, a Kuwaiti-born and British-raised terrorist, who had left the United Kingdom for Syria in 2013.

With al-Qaida's leadership perceived by some as having been decimated, Emwazi helped sharpen minds within the government about the scale of the security problem the United Kingdom still faced. For several years, British citizens had been leaving to fight the Bashar al-Assad regime in Syria and joining rebel factions with varying commitment to Islamist ideology. Britons traveling to jihadi conflict zones around the world was nothing new. Syria and the call of the caliphate was on a different scale. Over 900 people would ultimately leave the United Kingdom for Syria. ${ }^{62}$ Approximately $20 \%$ would be killed there, with some $40 \%$ returning to the United Kingdom. ${ }^{63}$

Now, a Briton was on screens around the world beheading civilians and warning British citizens that the Islamic State "will continue to wage jihad, break borders and one day invade your land where we will rule by the Sharia." ${ }^{64}$ Finally, the government chose to step up its response to the foreign fighter phenomenon.

Most strikingly, the government targeted its own citizens overseas via drone strikes. In August 2015, the Royal Air Force killed Reyaad Khan in the Islamic State's capital of Raqqa, Syria. ${ }^{65}$ The government acted after British intelligence assessed that Khan and a fellow Brit-Junaid Hussain, who was killed in a U.S. drone strike in August 2015-were using social media to plan attacks in the West "on an unprecedented scale." ${ }^{6}$ This included plans to kill a U.S. airman stationed in the United Kingdom and a plot to target Victory in Europe Day and Armed Forces Day celebrations. ${ }^{67}$

The United Kingdom also increasingly used its citizenship-stripping powers of dual nationals who had left the country to engage in terrorist activity. This power, available to the government long before the conflict in Syria, began to be deployed far more regularly. ${ }^{6}$ Some, including a government independent reviewer, were critical of the policy due to a lack of due process. ${ }^{69}$

Yet the Immigration Act of 2014 strengthened these powers further, enabling the home secretary to strip even naturalized Brits of their citizenship provided it did not result in them being made stateless and the individual in question had "conducted him or herself in a manner which is seriously prejudicial to the vital interests of the United Kingdom.."70

More powers became available to the government following the Counter-Terrorism and Security Act 2015, with the government using the Royal Prerogative to provide police with the power to remove the 
passports "of those who want to travel abroad to engage in terrorism." ${ }^{\text {"1 }}$ In the same act, Temporary Exclusion Orders made it illegal for a British citizen "suspected of involvement in terrorist-related activity abroad" to return to the United Kingdom from overseas without checking with British authorities beforehand. ${ }^{72}$

This led police to question foreign fighters and, theoretically, increase the prospect of prosecution. Bringing such individuals to court, however, was an area where the United Kingdom has struggled: only $10 \%$ of foreign fighter returnees from Syria and Iraq have been prosecuted. ${ }^{73}$ This was due to jurisdictional, legal, and practical issues regarding the collection of evidence from a war zone and its subsequent use in a civilian court. ${ }^{74}$ Some legislative effort has been made to close loopholes to allow more prosecutions in the future. The Serious Crime Act 2015 amended the Terrorism Act 2006 to ensure that extra-territorial jurisdiction now applied to those preparing to commit or assist another in an act of terrorism or those who provide or receive terrorist training.

The government's logic was that

extending the territorial jurisdiction in respect of these offenses may allow for prosecutions of people preparing or training more generally for terrorism who have, for example, traveled from the United Kingdom to fight in Syria, where various terrorist groups, including al-Qaida affiliated groups, are involved in the conflict. ${ }^{75}$

While this is correct, it was also correct in the 1990s and in 2006 when the Terrorism Act was passed. Foreign fighter travel had simply not been treated with the seriousness it deserved until years into the Syria conflict.

The government also passed the Counter-Terrorism and Border Security Act 2019, which extended the extra-territorial jurisdiction the government had over terrorism offenses. ${ }^{76}$ It created an offense of "entering, or remaining in, an area outside the United Kingdom that has been designated in regulations made by the Home Secretary." ${ }^{\prime 7}$ In practice, this meant just the act of travel to a jihadi conflict zone such as Syria without a reasonable excuse was now an offense punishable by up to 10 years in prison. It could not, however, be applied retrospectively to foreign fighters who left the United Kingdom prior to the law being passed and was therefore of limited utility with regard to Syria. ${ }^{78}$

While updating legislation, the government also stepped up its efforts to tackle the upstream threat. In October 2015, it published the first ever Counter-Extremism Strategy, a groundbreaking attempt to address the wider harms of extremism. The strategy set out commitments for departments and regulators across government in five areas: increasing understanding of extremism, countering extremist ideology, building partnerships with those within communities opposing extremism, disrupting extremists, and building more cohesive communities. ${ }^{79}$

The strategy also promised new targeted powers-such as banning orders and disruption orders- to disrupt extremists and "key radicalizers" who spread extremist views but had not broken the law. ${ }^{80}$ The context for this was the deliberately provocative public activities of Anjem Choudhury, the extremist cleric and leader of al-Muhajiroun, whose Islamist supporters had murdered British soldier Lee Rigby in South London in May 2013. ${ }^{81}$

In his foreword to the strategy, Cameron was clear about its rationale:

We know that terrorism is really a symptom; ideology is the root cause. But the stakes are now rising. The menace of [the Islamic State] and the sophisticated efforts of extremists to groom and radicalize young British people demands a response of a different magnitude. ${ }^{82}$

In response to this uptick in the attractiveness of the Islamic State and its self-declared caliphate, the Counter-Extremism Strategy laid out plans for a cultural counterinsurgency to defeat Islamist extremism and address its root causes. 
In 2015, in response to increasing numbers of British citizens and residents leaving the United Kingdom for Syria, the government moved to place Prevent on a statutory footing, making it a legal requirement for the police, prisons, local authorities, schools, and universities to put in place safeguards to prevent people from being drawn into terrorism. Home Office data on the five years since the duty came into force shows between 5,700 and 7,000 individuals were referred to the program annually due to concerns that they were at risk of radicalization, with a smaller number subsequently referred for specialist, multi-agency support known as Channel..$^{83}$

Such moves were an understandable response to the latest iteration of the Islamist terrorism threat. In 2017, however, the counterterrorism apparatus was tested once again after three Islamist terrorist attacks occurred between March and June, with a fourth attack carried out by a far-right terrorist - motivated by an ideology of hate toward Muslims - shortly thereafter. Together, these attacks killed 36 people. Later in 2017, an Iraqi teenager, motivated by the Islamic State's extremism and a hatred of Britain, ${ }^{84}$ partially exploded a bomb on a London underground train, injuring over 50 people. ${ }^{85}$

These attacks made it clear that the nature of the terrorism threat was becoming increasingly complex and changing rapidly. ${ }^{86}$ In the years following the $7 / 7$ attacks, the most serious terrorists typically engaged in long-term planning that often involved explosives or terrorist training overseas. Al-Qaida had retained its ability to deliver centrally directed attacks in the United Kingdom, with suicide a frequent feature. ${ }^{87}$

Over time, however, terrorism had diversified to include less sophisticated methods, often using vehicles or knives with a relatively short planning period but with a lethal effect. For counterterrorism policing, online radicalization was also an increasingly common component of terrorism cases. The number and tempo of credible threats were high and evolving, with rapid, low-tech attacks featuring alongside more traditional sophisticated bombings.

In response, the United Kingdom attempted to ensure its counterterrorism apparatus remained fit for purpose to deal with this different type of threat. Its counterterrorism strategy, CONTEST, is built around four pillars: Prevent, to stop people becoming terrorists or supporting terrorism; Pursue, to stop terrorist attacks; Protect, to strengthen our protection against a terrorist attack; and Prepare, to mitigate the impact of a terrorist attack. The British government updated CONTEST in June 2018 to reflect the shift in capabilities in response to the evolving terrorism threat and to take into account the recommendations from MI5, the British security service, and the Counter Terrorism Policing's Operational Improvement Review. To improve operational effectiveness, several key themes emerged. ${ }^{88}$

First, the review made recommendations to improve the ability of MI5 and the police to exploit big data to better detect activity of concern across the spectrum of risk, from initial leads, through priority investigations, to closed subjects of interest.

Second, the review urged multi-agency work across the intelligence community and between MI5 and Counter Terrorism Policing. The 2017 attacks in London and Manchester highlighted the challenges of identifying potential attackers and the pace at which plots can move to violence. The review won a commitment by MI5 to allow knowledge derived from intelligence to be shared more widely beyond intelligence circles, enabling, for example, neighborhood policing to better understand risk and put in place early interventions.

Third, the review called for consistent assessment and investigation of all terrorist threats, notably the evolving and growing risk posed by far right terrorism. As a result, in April 2020, MI5 and the Joint Terrorism Analysis Center replaced the police as the lead agency for detecting far right terrorism. ${ }^{89}$

The shift in the nature of the terrorism threat has also led to a greater emphasis on the ways in which different counterterrorism working strands interact. CONTEST 2018 introduced leveraging people who have previously engaged in terrorism as a new element to Prevent. The Desistance and Disengagement Program was designed to manage the risk from returning foreign fighters or terrorism prisoners on license. It was also intended to complement the work being done under Pursue to "disrupt terrorist activity, 
including through prosecutions." ${ }^{90}$ The widening of Prevent to include working with people who had already crossed the threshold into criminal activity was a significant policy shift away from the program's previous emphasis on the "non-criminal" space. ${ }^{91}$

In the United Kingdom, as elsewhere, there has been a greater recognition on the ability of terrorist groups to exploit permissive spaces online and a corresponding focus on preventing the dissemination of terrorist material online. A unit within the Metropolitan Police's Counter Terrorism Command works with the internet companies to remove online content that incites or glorifies terrorism, ${ }^{92}$ and proscription of far right terrorist groups and their aliases is now seen as a tool to take down material associated with these groups. ${ }^{93}$

The United Kingdom is pursuing online safety legislation that would place responsibilities on technology companies regarding the management and removal of terrorist content. In December 2020, the government published its latest proposals for the upcoming Online Safety Bill, which will introduce a new duty of care on companies to improve user safety overseen by the independent regulator Ofcom. One contested area remains the responsibilities placed on certain (typically high-reach) technology companies for handling so-called "legal but harmful" content, which may include extremist or hate material. ${ }^{94}$

\section{Diversity of European response}

Islamist terrorism is clearly not just a concern for the United Kingdom. Terrorists have conducted attacks throughout Europe over the decades. How that has manifested itself country by country has varied slightly. The response to this, too, has widely differed.

In France, for example, the terrorism threat has a distinctive (although certainly not exclusive) homegrown element. High-profile attacks from the last decade-for example, Mohamed Merah's March 2012 shooting spree, the al-Qaida operation on Charlie Hebdo magazine in January 2015, and Amedy Coulibaly's attacks on police forces and Jewish civilians days later-were carried out by French citizens.

French citizens also formed the bulk of the cell that carried out the Islamic State's coordinated attacks across Paris in November 2015. The cell's ringleader, Abdelhamid Abaaoud, was Belgian, highlighting the localized element of the threat in France. In this regard, there are similarities between France and the United Kingdom, where $72 \%$ of all Islamism-related offenses committed between 1998 and 2015 were committed by UK nationals or individuals holding British nationality. ${ }^{95}$

The Islamist terrorist threat in other countries has less of a homegrown component. Germany is an obvious example of how security problems can be linked to asylum policies. Germany disrupted 11 terrorist plots between 2000 and 2013, ${ }^{96}$ suffering no major Islamist terrorist attacks in this period. ${ }^{97}$ Instead, Germany was largely focused on dealing with flare-ups from white supremacists. For example, neo-Nazi murders of Turkish small business owners at the turn of the century demonstrated a clear and ongoing issue with far-right terrorism. ${ }^{98}$

Then, between 2015 and 2017, Germany accepted nearly 1.5 million asylum seekers, mainly from Muslim-majority countries wracked by war: Afghanistan, Iraq, and Syria. ${ }^{99}$ Germany has suffered from numerous Islamist terrorist attacks since, a significant number of which were carried out by recent arrivals claiming asylum. ${ }^{100}$

The European attitude toward Muslim asylum seekers is far from universal. For example, Sweden took a similarly welcoming approach to Germany, accepting 163,000 asylum seekers in 2015. As a proportion of the population, this was the equivalent of the United States accepting over 5 million in a single year. Yet some Eastern European countries-Poland and Hungary, for example - took a far more guarded approach, explicitly citing security concerns. ${ }^{101}$

European countries have also placed contrasting levels of importance on early intervention programs similar to Prevent. Italy, for example, is far less concerned about such initiatives or even building criminal 
cases for prosecution. Its aim is disrupting plotting at an early stage and taking a forward-leaning and expansive approach to deportation of foreign nationals who pose a suspected threat. ${ }^{102}$

Yet even those countries that have emphasized the importance of intervention programs take different approaches to conception and implementation. Where the United Kingdom has been willing to delve into ideology, for example, Sweden and Finland are far more cautious about involving themselves in such thorny matters, preferring to focus on addressing inequalities and grievances. ${ }^{103}$

All European countries, however, are to some extent reliant on diligent intelligence services and law enforcement to stop terrorist plotting. Post-9/11, such efforts were given greater emphasis in Europe than in the United States, whose superior war-fighting capacity gave it the option to take the fight to jihadi groups overseas in a manner that most European countries did not possess. This inevitably led to a more militarized approach in the United States and helped exacerbate fundamental philosophical differencesfor example, over the morality concerning law of war detentions-between Europe and the United States.

A collective experience that Europe and the United States did share after 9/11 was in learning how to break down more intelligence and policing firewalls domestically. This has involved not only restructuring bureaucracies but also persuading intelligence agencies protective of sensitive information to trust other parts of the government with that information. ${ }^{104}$ While far from perfect, countries such as Italy and the United Kingdom, which have historical experience facing such issues due to the operation of active domestic terrorist movements in the pre-9/11 era, have often fared better in this task than other European counterparts. ${ }^{105}$

The process has proven more complicated in France, where a July 2016 parliamentary investigation found an unwieldy bureaucracy with six intelligence agencies reporting to different government ministries (economic, national defense, the interior) and which collected significant information but failed to sufficiently connect dots. ${ }^{106}$

The improvements still required at the nation-state level help explain why talk of broader pan-European intelligence sharing initiatives - a "European CIA," in the words of ex-Belgian Prime Minister Charles Michel-are premature. ${ }^{107}$ Not only are there more pressing intelligence sharing issues that need to be resolved at the state level, but intelligence agencies will remain wary of divulging sensitive information to other countries, even their European Union allies.

After all, the consequences of over-sharing can be deadly. As the former head of Britain's foreign intelligence service MI6, John Sawers, spelled out, "no intelligence service risks compromising its sources. . . . Because whenever intelligence is revealed, others try to hunt down the source. Agents can get identified, arrested, tortured, and killed." ${ }^{108}$ It is clear that improving intelligence sharing is critical to preventing terrorist attacks. Yet the precise mechanics for doing so remain complex at both a local and state level.

\section{What comes next}

The fall of the self-declared caliphate has reduced the momentum the Islamic State possessed. This loss of territory, along with reverses on the battlefield, has dented the group's appeal to potential new recruits. The United States and its allies have killed key terrorist planners in Syria and Iraq who had been targeting Europe. The Islamic State is also no longer able to use its control of territory as a springboard from which to launch external attacks. ${ }^{109}$ Furthermore, the pace of foreign fighter plots seems to have slowed since 2016.

Despite these welcome developments, it is certain that the Islamist terrorist threat facing the United Kingdom and Europe will endure. After all, plotting continued in Europe after March 2019, which was when the last town in the Islamic State's caliphate was recaptured in Syria. In the 15 months that followed, there were, on average, two Islamist terrorism plots per month either successfully executed or thwarted in Europe. Most perpetrators acted alone and did not have direct organizational links to the Islamic State. ${ }^{110}$ 
Then there are those whose previous attempts to travel to conflict zones were thwarted and who are instead looking to lash out closer to home. Kujtim Fejzulai, the Austrian Macedonian who killed four and injured 23 in a firearms attack in Vienna in November 2020 is an example. He had unsuccessfully attempted to travel to both Syria and Afghanistan prior to carrying out his attack in Austria. ${ }^{111}$ There have been dozens of similar plots across Europe. ${ }^{112}$

Another security concern are jihadi prisoners who have been released from prison in various European countries. Several Islamist attacks and alleged plots in France, the United Kingdom, and Germany in recent years have involved individuals who had been released from detention having previously been convicted of at least one terrorism offense. Cherif Kouachi, one of the gunmen in the Charlie Hebdo attack, had previously been convicted of a terrorism-related offense in France after he was arrested preparing to leave for Iraq to take part in fighting there. ${ }^{113}$

Furthermore, while foreign fighter plotting has slowed, such individuals do not have to be actively planning atrocities to constitute a national security threat. The "credibility" they have gained by fighting overseas can be utilized to recruit others for future conflicts.

These disparate threats need to be addressed. There also should be a broader reconceptualization of the risks posed by Islamist extremism. Without more strategic thinking across the continent, Europe will be reduced to just having to deal with the most imminent terrorist plot in perpetuity. That is both an unwelcome and unsustainable prospect. Therefore, the entire ecosystem from which terrorists recruit needs addressing. Taking a more robust approach towards Islamism will lead to some uncomfortable conversations on theology, freedom of speech, and democratic values.

\section{Notes}

1 This includes four Islamist terrorist attacks and one attack from the far right.

2 Northern Ireland faces a profoundly different threat from terrorism and has been omitted from this analysis.

3 Islamist terrorists caused 91 of these deaths, 3 were caused by the far right, and 3 by a perpetrator whose ideology is currently unclear. See Vikram Dodd, "Khairi Saadallah Pleads Guilty to Three Murders," Guardian, November 11, 2020, www.theguardian.com/uk-news/2020/nov/11/reading-terror-attacker-khairi-saadallah-pleads-guilty-to.

4 Home Office, CONTEST: The United Kingdom's Strategy for Countering Terrorism (London: HM Government, 2018).

5 Kim Knott, Muslims and Islam in the UK: A Research Synthesis (Lancaster, UK: Centre for Research and Evidence on Security Threats, 2018), 47.

6 For more detail on Jamaat-i-Islami, see Matthew Wilkinson, The Genealogy of Terror (London: Routledge, 2019).

7 Damon L. Perry, Mainstream Islamism in Britain: Educating for the "Islamic Revival" (London: Commission for Countering Extremism, 2019), 1.

8 Home Office, Muslim Brotherhood Review: Main Findings (London: HM Government, 2015), para. 20.

9 Perry, Mainstream Islamism in Britain, 2.

10 Home Office, Muslim Brotherhood Review, paras. 23-24.

11 Ibid., para. 22.

12 For more detail on the emergence of Salafi-jihadi ideology in the United Kingdom, see Shiraz Maher, SalafiJihadism: The History of an Idea (London: Hurst, 2016).

13 Maajid Nawaz, "Bosnia Changed My Life," Emel no. 91 (2012).

14 "Abu Muslim Al-Turki," Caravan of Martyrs, accessed December 5, 2020, http://caravansofmartyrs.atspace.com/ html/Abu_Muslim_Al-Turki.htm.

15 "The Terrorist Diaspora: After the Fall of the Caliphate: Testimony Before the Committee on Homeland Security," 115th Cong. (2017) (statement of Robin Simcox, Margaret Thatcher Fellow, The Heritage Foundation).

16 For more detail on these dynamics within British Muslim communities in the United Kingdom during the 1990s, see Rafaello Pantucci, “We Love Death as You Love Life” Britains' Suburban Terrorists (London: Hurst, 2015).

17 Michael Clarke, "The Contract with Muslims Must Not Be Torn Up," Guardian, August 26, 2005, www.theguardian.com/politics/2005/aug/26/terrorism.religion.

18 Hannah Stuart, Islamist Terrorism: Analysis of Offences and Attacks in the UK (1998-2015) (London: Henry Jackson Society, 2017). 
19 Tony Blair, "Blair's Statement in Full," BBC, September 11, 2001, http://news.bbc.co.uk/1/hi/uk_politics/ 1538551.stm.

20 Ministry of Defense, “Operations in Afghanistan: Chronology of Events, September 2001-December 2002” (London: UK Ministry of Defense, no date).

21 Nick Hopkins, "British Muslims Who Fought with Taliban Face Prosecution,” Guardian, November 20, 2001, www.theguardian.com/uk/2001/nov/20/september11.world; James Kirkup, "British Muslims Fighting Alongside Taliban, Commanders Claim," Daily Telegraph, January 2, 2009, www.telegraph.co.uk/news/worldnews/asia/ afghanistan/4076591/British-Muslims-fighting-alongside-Taliban-commanders-claim.html.

22 "UK Muslims 'Killed' in Afghanistan,” BBC, October 29, 2001, http://news.bbc.co.uk/1/hi/uk/1625115.stm.

23 “The Guantanamo Docket: Citizens of Britain," New York Times, accessed December 6, 2020, www.nytimes.com/ interactive/projects/guantanamo/country/britain.

24 Stuart, Islamist Terrorism, 2-6.

25 Ibid., 4-5.

26 Anti-Terrorism, Crime and Security Bill, House of Commons, session 2001-02, https://publications.parliament. $\mathrm{uk} / \mathrm{pa} / \mathrm{cm} 200102 / \mathrm{cmbills} / 049 / \mathrm{en} / 02049 \mathrm{x}--$.htm.

27 House of Lords, Judgments-A (FC) and others (FC) (Appellants) v. Secretary of State for the Home Department (Respondent), UK Parliament, session 2004-05, December 16, 2004, para. 11, https://publications.parliament.uk/pa/ ld200405/ldjudgmt/jd041216/a\&oth-1.htm.

28 Chahal v. The United Kingdom, 22414/93 (Grand Chamber, 1996), www.bailii.org/eu/cases/ECHR/1996/54. html.

29 Anti-terrorism, Crime and Security Act 2001, UK Parliament, www.legislation.gov.uk/ukpga/2001/24/section/ 30/2001-12-14.

30 Stuart, Islamist Terrorism, 18-19.

31 Ibid., 86-88.

32 Douglas Murray, “Abu Hamza Embodies Britain’s Self-Destructive Madness,” Spectator, May 20, 2014, www.spectator.co.uk/article/abu-hamza-embodies-britain-s-self-destructive-madness.

33 “London Bomber: Text in Full," BBC, September 1, 2005, http://news.bbc.co.uk/1/hi/uk/4206800.stm.

34 Tony Blair, "Full Text: The Prime Minister's Statement on Anti-Terror Measures," Guardian, August 5, 2005, www.theguardian.com/politics/2005/aug/05/uksecurity.terrorism1; Patrick Wintour, "Blair Vows to Root Out Extremism," Guardian, August 6, 2005, www.theguardian.com/politics/2005/aug/06/terrorism.july7.

35 Michael Bates, "Exclusion Orders: Question for Home Office UIN HL4168," UK Parliament, January 22, 2015, https://questions-statements.parliament.uk/written-questions/detail/2015-01-14/HL4168.

36 Home Office, Proscribed Terrorist Organisations (London: HM Government, 2020), 7-8.

37 For more on Hizb-ut-Tahrir, see Houriya Ahmed and Hannah Stuart, Hizb ut Tahrir: Ideology and Strategy (London: Centre for Social Cohesion, 2009), 61, 109-111.

38 Home Office, CONTEST, 8.

39 Home Office, 'Preventing Extremism Together' Working Groups: August-October 2005 (London: HM Government, 2005), 1.

40 Home Office, Countering International Terrorism: The United Kingdom's Strategy (London: HM Government, 2006), 1-2; Home Office, Pursue Prevent Protect Prepare the United Kingdom's Strategy for Countering International Terrorism (London: HM Government, 2009), 14.

41 Home Office, The Prevent Strategy: A Guide for Local Partners in England (London: HM Government, 2008$), 5$.

42 Russell Jenkins, "Killers May Have Been Recruited at Youth Centre," The Times, July 16, 2005, www.thetimes. co.uk/article/killers-may-have-been-recruited-at-youth-centre-nzpkfrq9tph.

43 Department for Communities and Local Government, Preventing Violent Extremism Pathfinder Fund 2007/08: Case Studies (London: Department for Communities and Local Government, 2007), 4.

44 Vikram Dodd, “Government Anti-Terrorism Strategy 'Spies' on Innocent,” Guardian, October 16, 2009 , www. theguardian.com/uk/2009/oct/16/anti-terrorism-strategy-spies-innocents.

45 Arshad Isakjee and Chris Allen, “ “A Catastrophic Lack of Inquisitiveness': A Critical Study of the Impact and Narrative of the Project Champion Surveillance Project in Birmingham," Ethnicities 13, no. 6 (2013): 753.

46 Tufyal Choudhury and Helen Fenwick, The Impact of Counter-Terrorism Measures on Muslim Communities (Manchester: Equality and Human Rights Commission, 2011), iii.

47 The Labour government suspended dialogue with the Muslim Council of Britain in 2009 because of its support for the Istanbul Declaration, an Islamist proclamation which justified attacks on British forces enforcing an arms blockade on Gaza, and there has been no substantive dialogue since then. Ministers have rejected recent efforts by the Muslim Council of Britain to obtain dialogue.

48 Home Office, Radicalisation: The Counter-Narrative and Identifying the Tipping Point (London: HM Government, 2017). 


\section{The UK's approach to counterterrorism}

49 Mockbul Ali, "Shaykh Yusuf al Qaradawi," Memorandum to the Home Secretary, July 14, 2005, http://image.guardian. co.uk/sys-files/Observer/documents/2005/09/04/Document1.pdf.

50 Shiraz Maher and Martyn Frampton, Choosing Our Friends Wisely: Criteria for Engagement With Muslim Groups (London: Policy Exchange, 2009); Home Office, Prevent Strategy (London: HM Government, 2011).

51 Ibid.

52 David Cameron, "PM’s Speech at Munich Security Conference," Prime Minister's Office, February 5, 2011, www. gov.uk/government/speeches/pms-speech-at-munich-security-conference.

53 Ibid.; David Cameron, "Extremism," Prime Minister's Office, July 20, 2015, www.gov.uk/government/speeches/ extremism-pm-speech.

54 Home Office, Prevent Strategy.

55 House of Lords, Judgments $-A(F C)$ and others $(F C) v$. Secretary of State.

56 Prevention of Terrorism Act 2005, UK Parliament, www.legislation.gov.uk/ukpga/2005/2/pdfs/ukpga_2005 0002_en.pdf.

57 Robin Simcox, Control Orders: Strengthening National Security (London: Centre for Social Cohesion, 2010).

58 Home Office, Counter-Terrorism Policy and Human Rights (Fourteenth Report): Annual Renewal of Control Orders Legislation 2009 (London: HM Government, 2009).

59 Terrorism Prevention and Investigation Measures Act 2011, UK Parliament, www.legislation.gov.uk/ukpga/ 2011/23/contents/enacted.

60 David Anderson, Deportation With Assurance (London: HM Government, 2017).

61 "Abu Qatada Cleared of Terror Charges," BBC, September 24, 2014, www.bbc.co.uk/news/world-29340656.

62 Sajid Javid, “UK Nationals Returning From Syria: Volume 654,” UK Parliament, February 18, 2019, https:// hansard.parliament.uk/commons/2019-02-18/debates/69E286BB-03A2-4467-AB65-B3059436CD53/ UKNationalsReturningFromSyria.

63 Home Office, CONTEST, 18.

64 Lizzie Dearden, “ISIS Video: Full Transcript of 'A Message to David Cameron',' Independent, January 5, 2016, www.independent.co.uk/news/uk/home-news/isis-video-full-transcript-message-david-cameron-siddharthadhar-isa-dare-a6797671.html.

65 Killed alongside Khan was Ruhil Amin, another British Islamic State recruit.

66 Intelligence and Security Committee of Parliament, UK Lethal Drone Strikes in Syria (London: HM Government, 2017).

67 "Father Fears Sons Are on 'Hit List' After Reyaad Khan Drone Strike," BBC, September 8, 2015, www.bbc.com/ news/uk-wales-34183320; "US Airmen Terror Attack: Junead Khan Found Guilty," BBC, April 1, 2016, www. bbc.com/news/uk-35944661.

68 Lizzie Dearden, "Shamima Begum: Number of People Stripped of UK Citizenship Soars by $600 \%$ in a Year," Independent, February 20, 2019, www.independent.co.uk/news/uk/home-news/shamima-begum-uk-citizenshipstripped-home-office-sajid-javid-a8788301.html.

69 Ibid.

70 Immigration Act 2014, UK Parliament, www.legislation.gov.uk/ukpga/2014/22/section/66/enacted.

71 Home Office, "Factsheet-The Counter-Terrorism and Security Bill" (London: HM Government, no date).

72 Home Office, "Factsheet-Part 1 Chapter 2-Temporary Exclusion Orders, Counter-Terrorism and Security Bill" (London: HM Government, no date).

73 Lizzie Dearden, "Only One in 10 Jihadis Returning from Syria Prosecuted, Figures," Independent, February 21, 2019, www.independent.co.uk/news/uk/home-news/shamima-begum-isis-return-uk-syria-jihadis-terror-threatprosecute-nationality-a8790991.html.

74 For an exploration of these issues as related to the wars in Afghanistan and Iraq, see Robin Simcox, The Presumption of Innocence: Difficulties in Bringing Suspected Terrorists to Trial (London: Henry Jackson Society, 2013).

75 Serious Crime Act 2015, UK Parliament, www.legislation.gov.uk/ukpga/2015/9/notes.

76 Home Office, "Counter-Terrorism and Border Security Act 2019 Terrorism Offences Fact Sheet" (London: HM Government, no date).

77 Home Office, "Counter-Terrorism and Border Security Act 2019 Designated Area Offence Fact Sheet" (London: HM Government, no date).

78 Ibid.

79 Home Office, Counter-Extremism Strategy (London: HM Government, 2015).

80 Ibid., 6.

81 Raffaello Pantucci, "How Lee Rigby's Murder Changed the Face of Terror," Guardian, April 15, 2018, www.theguardian.com/commentisfree/2018/apr/15/day-new-terror-unleashed-lee-rigby-murder-woolwich.

82 Home Office, Counter-Extremism Strategy, 5. 
83 Home Office, Individuals Referred To and Supported Through the Prevent Programme, April 2019 to March 2020 (London: HM Government, 2020).

84 Judiciary of England and Wales, The Queen v. Ahmed Hassan: Sentencing Remarks of the Hon. Mr Justice Haddon-Cave (London: Judiciary of England and Wales, 2018), para. 17.

85 Ian Cobain, "Parsons Green Tube Bomber Ahmed Hassan Jailed for Life," Guardian, March 23, 2018, www.theguardian.com/uk-news/2018/mar/23/parsons-green-tube-bomber-ahmed-hassan-jailed-for-life.

86 Kate Forrester, "Reading Attack: Threat From 'Lone Actors' Growing, Warns Priti Patel,' Politics Home, June 22, 2020, www.politicshome.com/news/article/threat-from-lone-actors-growing-warns-priti-patel-in-wake-of-read ing-stabbing-attacks.

87 Peter Clarke, Learning from Experience: Counter Terrorism in the UK Since 9/11 (London: Policy Exchange, 2007).

88 David Anderson, Implementation Stock Take: Unclassified Summary of Conclusions (London: HM Government, 2019), 2.

89 Home Office, "Fact Sheet: Right-Wing Terrorism," Home Office in the Media (blog), September 20, 2019, https:// homeofficemedia.blog.gov.uk/2019/09/20/fact-sheet-right-wing-terrorism/.

90 Home Office, CONTEST, 8, 29 and 40.

91 National Health Service, Prevent: Basic Prevent Awareness Level 1 and 2 (London: National Health Service), 3.

92 “Together We're Tackling Online Terrorism," Counter Terrorism Policing, December 19, 2018, www.counterterrorism.police.uk/together-were-tackling-online-terrorism/.

93 James Brokenshire, "Security Minister Speech to the Royal United Services Institute" (London: HM Government, 2020), www.gov.uk/government/speeches/security-minister-speech-to-the-royal-united-services-institute.

94 Home Office, Online Harms White Paper: Full Government Response to the Consultation (London: HM Government, 2020).

95 Stuart, Islamist Terrorism.

96 “11 Terror Plots Foiled in Germany Since 2000," The Local, March 29, 2016, www.thelocal.de/20160329/ german-security-service-saves-its-sheep-from-terrorism.

97 Islamist terrorism, however, was still a factor during this period. See Robin Simcox, "Merkel's Generous Refugee Policy Puts Germany at Risk," National Review, August 9, 2017, www.nationalreview.com/2017/08/ angela-merkel-refugee-policy-threatens-german-security-islamist-terrorism/.

98 Iveta Ondruskova, “The Victims of the Neo-Nazi NSU Murder Spree," Die Welle, June 10, 2018, www.dw.com/ en/the-victims-of-the-neo-nazi-nsu-murder-spree/g-44606301.

99 “German Interior Minister Revises 2015 Refugee Influx From 1.1 Million to 890,000," Deutsche Welle, September 30, 2016, www.dw.com/en/german-interior-minister-revises-2015-refugee-influx-from-11-million-to890000/a-35932746; Federal Ministry of the Interior, Asylum Seekers in 2017 (Berlin: Federal Ministry of the Interior, 2018).

100 Robin Simcox, The Asylum — Terror Nexus: How Europe Should Respond (Washington, DC: Heritage Foundation, 2018).

101 Matthew Kaminski, “All the Terrorists Are Migrants," Politico, November 23, 2015. www.politico.eu/article/ viktor-orban-interview-terrorists-migrants-eu-russia-putin-borders-schengen/; "Terrorism Linked to Migration: Polish President," Radio Poland, September 15, 2017, http://archiwum.thenews.pl/1/10/Artykul/325885, Terrorism-linked-to-migration-Polish-president.

102 Robin Simcox, "Is Italy Immune From Terrorism?" Foreign Policy, July 18, 2019, https://foreignpolicy.com/ 2019/07/18/is-italy-immune-from-terrorism/.

103 Robin Simcox, "Scandinavian Approach to Counterterrorism, Islamist Ideology Is Flawed," The Daily Signal, May 11, 2018, www.dailysignal.com/2018/05/11/scandinavian-approach-to-counterterrorism-islamist-ideologyis-fatally-flawed/.

104 Robin Simcox, "Europe, Stop Trying To Make 'Intelligence Sharing' Happen,” Foreign Policy, April 14, 2016, https://foreignpolicy.com/2016/04/14/europe-stop-trying-to-mak-brussels-paris-bombings/.

105 Simcox, "Is Italy Immune From Terrorism?".

106 Robin Simcox, "French Intelligence Reform: The Counterterrorism Commission Won't Prevent the Next Attack," Foreign Affairs, July 17, 2016, www.foreignaffairs.com/articles/france/2016-07-17/french-intelligence-reform.

107 Euronews, "Belgium's PM Michel Calls for a European CIA," Euronews, November 30, 2015, www.euronews. com/2015/11/30/belgium-s-pm-michel-calls-for-a-european-cia.

108 John Sawers, “Sir John Sawers's Speech," Guardian, October 28, 2010, www.theguardian.com/uk/2010/oct/28/ sir-john-sawers-speech-full-text.

109 Robin Simcox, The Post-Caliphate Terror Threat in Europe-And the Need for Continuing U.S. Assistance (Washington, DC: The Heritage Foundation, 2018).

110 Robin Simcox, Europe and the Fall of the Caliphate (London: Counter Extremism Group, 2020). 


\section{The UK's approach to counterterrorism}

111 Oliver Moody, "Vienna Terrorist Kujtim Fejzulai, a Football-Crazed Boy Who Became a Cold-Blooded Gunman," The Times, November 7, 2020, www.thetimes.co.uk/article/vienna-terrorist-kujtim-fejzulai-a-foot ball-crazed-boy-who-became-a-cold-blooded-gunman-pmpjbpn99.

112 Robin Simcox, "When Terrorists Stay Home: The Evolving Threat to Europe From Frustrated Travelers," CTC Sentinel 12, no. 6 (2019): 46-55.

113 Andrew Higgins and Maïa de la Baume, "Two Brothers Suspected in Killings Were Known to French Intelligence Services," New York Times, January 8, 2015, www.nytimes.com/2015/01/08/world/two-brothers-suspected-inkillings-were-known-to-french-intelligence-services.html. 